\title{
Obituary for Professor Michael Steurer
}

Alexander Egle

Published online: 2 May 2019

(C) Springer-Verlag GmbH Austria, part of Springer Nature 2019

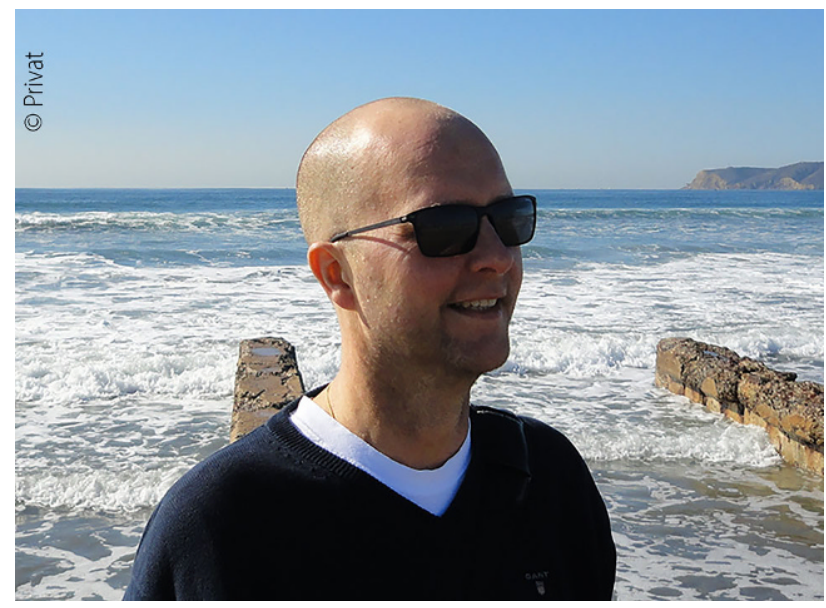

Prof. Michael Steurer

Michael Steurer was my big, strong, great friend. He left us on March 11, 2019 after fighting his bravest battle against a disease he knew so well from years of treating his patients. He left a mourning wife and two fantastic daughters at age of three and six. He was a wonderful father and devoted husband and was enormously proud and happy to have his family. The catastrophic disease, with its final result-his much too early departure-leaves us all speechless and stunned. He was a very special person to have known.

PD Dr. A. Egle ( $ه)$

Third Medical Department with Hematology and Medical Oncology, Paracelsus Medical University Salzburg, Müllner Hauptstraße 48, 5020 Salzburg, Austria

a.egle@salk.at
Prof. Michael Steurer was a great hematologist-academic and practical-and an inspired scientist with a never waning interest in all areas of hematology. He was often sought for advice by peers and was a renowned expert across a broad range of the hematological disease spectrum and a reference to many, as evidenced by the many second opinions that were asked from him-I include myself as one of many peers who received valuable lessons from him as a teacher.

Michael was a great academic-with a keen interest in science across a large array of topics. He was able to see the important issues by cutting through the noise - in his clinical life as well as in his science-and he asked the right questions that defined real value. He had published numerous papers in over 50 different journals and his work was cited over 2000 times. However, his scientific mind was not focused on building a career, but on the exploration of novel and important territory. His academic career was a mere byproduct of his delight to be scientifically productive. He was a Guest Editor for the journal MEMO for many years and wrote many insightful ASH update reports for the journal.

He was a knowing and kind teacher in his academic life. He mentored many and will be sorely missed by his institution. More than gaining respect in his peer group and work environment, his clarity and kindness inspired admiration and love in his institution.

One of his defining characteristics was a basic respect for people that made him a pleasant partner-even if he was always prepared to win an argument with his enormous knowledge, he never devalued the position of the others and never made a show out of being smart.

Michael grew up near the Rhine River, Germany, very close to Strasbourg and the French border. This exposure in a cultural contact point may explain his 
appreciation for diversity-and for fine (aromatic, sometimes stinky) cheeses. He grew up with his sister and his loving parents. His happy childhood was a foundation for a fulfilling life and career. After he attended Einstein High School in Kehl, he studied medicine in Freiburg, where he entered the scientific working group of Günther Gastl, whom he followed to Innsbruck, when Prof. Gastl received that call to head the Department of Hematology and Oncology there. He quickly established himself as a leading figure in the department and became the Deputy Director of the Department, before he received his terrible diagnosis.

Michael was a truly great man-this became especially apparent in his most challenging time. Despite his detailed knowledge of the disease he had to fight and the many foreboding signs that it might be stronger than him, he was never bitter, and remained an impeccable gentleman in all his interactions. I have never encountered a braver man!

But above all he was a man of unstoppable joie de vivre and of enormous wit. A charismatic and happy human with a large potential for joy and with electric energy and a keen love for nature. He was fun to be around and I cannot remember a boring moment with him! He was the happiest when he was with his family-he had arrived where he wanted to be! This only increases the weight of the unbelievable injustice that took this happiness away from him much too soon, and that leaves his beloved family with an unspeakable loss!

Michael Steurer was my big, strong, great friend. He left us on March 11, 2019. His memory as a hematologist, scientist, teacher, mentor, friend, father and husband will live on!

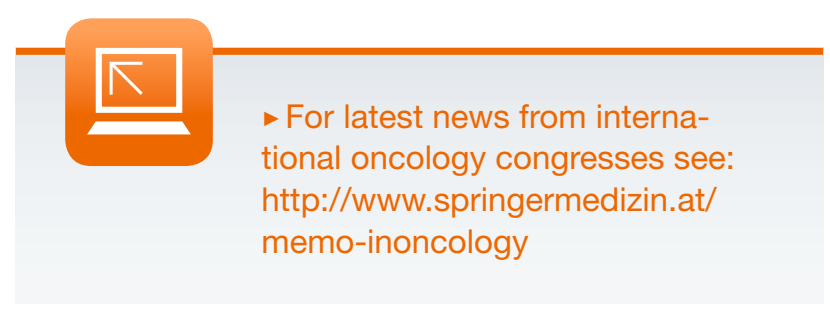

